\title{
Myoclonic Epilepsy in Gaucher Disease: Genotype-Phenotype Insights from a Rare Patient Subgroup
}

\author{
JOSEPH K. PARK, EDUARD ORVISKY, NAHID TAYEBI, CHRISTINE KANESKI, \\ MARY E. LAMARCA, BARBARA K. STUBBLEFIELD, BRIAN M. MARTIN, \\ RAPHAEL SCHIFFMANN, AND ELLEN SIDRANSKY
}

\begin{abstract}
Clinical Neuroscience Branch, National Institute of Mental Health [J.K.P., E.O., N.T., M.E.L., B.K.S., B.M.M., E.S.], Medical Genetics Branch, National Human Genome Research Institute [E.O., M.E.L., B.K.S., E.S.], and Developmental and Metabolic Neurology Branch, National Institute of Neurological Disorders and Stroke [C.K., R.S.], National Institutes of Health, Bethesda, Maryland, U.S.A.
\end{abstract}

\begin{abstract}
Gaucher disease, the inherited deficiency of lysosomal glucocerebrosidase, presents with a wide spectrum of manifestations. Although Gaucher disease has been divided into three clinical types, patients with atypical presentations continue to be recognized. A careful phenotypic and genotypic assessment of patients with unusual symptoms may help define factors that modify phenotype in this disorder. One such example is a rare subgroup of patients with type 3 Gaucher disease who develop progressive myoclonic epilepsy. We evaluated 16 patients with myoclonic epilepsy, nine of whom were diagnosed by age $4 \mathrm{y}$ with severe visceral involvement and myoclonus, and seven with a more chronic course, who were studied between ages 22 and 40. All of the patients had abnormal horizontal saccadic eye movements. Fourteen different genotypes were encountered, yet there were several shared alleles, including V394L (seen on two alleles), G377S (seen on three alleles), and L444P, N188S, and
\end{abstract}

\section{ABSTRACT}

recombinant alleles (each found on four alleles). V394L, G377S, and N188S are mutations that have previously been associated with non-neuronopathic Gaucher disease. The spectrum of genotypes differed significantly from other patients with type 3 Gaucher disease, where genotypes L444P/L444P and R463C/ null allele predominated. Northern blot studies revealed a normal glucocerebrosidase transcript, whereas Western studies showed that the patients studied lacked the processed $56 \mathrm{kD}$ isoform of the enzyme, consistent with neuronopathic Gaucher disease. Brain autopsy samples from two patients demonstrated elevated levels of glucosylsphingosine, a toxic glycolipid, which could contribute to the development of myoclonus. Thus, although there were certain shared mutant alleles found in these patients, both the lack of a shared genotype and the variability in clinical presentations suggest that other modifiers must contribute to this rare phenotype. (Pediatr Res 53: 387-395, 2003)
Gaucher disease (MIM 230800) is an autosomal, recessively inherited lysosomal storage disorder caused by the deficiency of the enzyme glucocerebrosidase (EC 3.2.1.45). The gene encoding for glucocerebrosidase is located on chromosome $1 \mathrm{q} 21$ and, to date, approximately 200 different mutations have been identified in DNA sequence from patients with Gaucher disease (1-5). Patients with Gaucher disease have been divided roughly into three clinical types, based upon the presence and rate of progression of neurologic symptoms. Type 1 Gaucher disease is the most common form and has no associated neurologic symptoms. However, patients with type 1 disease have a wide range of clinical presentations; they may be asymptomatic or have varied ages of onset and severity of

Received May 13, 2002; accepted October 4, 2002

Correspondence: Ellen Sidransky, M.D., Section on Molecular Neurogenetics, 49 Convent Drive, MSC4405, 49/B1EE16, Bethesda, MD 20892-4405, U.S.A.; e-mail: sidranse@irp.nimh.nih.gov

DOI: 10.1203/01.PDR.0000049515.79882.94 symptoms. Type 2 Gaucher disease, the rarest and most severe form, presents with progressive neurologic deterioration and results in fatality in utero or within the first $2-3$ y of life. Patients with type 3, or chronic neuronopathic Gaucher disease, generally have the onset of symptoms in childhood or in the early adult years, as well as some form of neurologic involvement. Some authors have further divided type 3 Gaucher disease into subtypes $3 \mathrm{a}, 3 \mathrm{~b}$, and $3 \mathrm{c}$ based upon the nature of the neurologic manifestations $(6,7)$, but many patients still do not fit well into any category. In fact, Gaucher disease can be seen as a disorder with a continuum of phenotypes ranging from perinatal lethality to asymptomatic adults, although some forms have brain involvement and others do not.

There has been a wealth of literature detailing the genotypic analysis of populations of patients with Gaucher disease. However, vast genotypic heterogeneity is encountered even among patients who are very similar clinically. Moreover, it has been noted that in some instances, patients with the same genotype 
will not necessarily share the same phenotype $(4,8,9)$. Thus, with certain notable exceptions (i.e. the association of mutation N370S with non-neuronopathic Gaucher disease), the predictive value of genotyping is somewhat limited.

Our appreciation of the full spectrum of clinical manifestations associated with Gaucher disease has continued to expand. An increasing number of subgroups of patients with Gaucher disease and unique phenotypes have been reported recently. Included among these are patients with parkinsonian symptoms $(10,11)$, pulmonary hypertension (12), cardiac calcifications and/or fibrosis (13-15), and hydrops fetalis or the collodion baby phenotype $(16,17)$. Unique phenotypes are especially prevalent among patients classified as having type 3 Gaucher disease. Even 27 y ago, Frederickson and Sloan (18) concluded that, "They undoubtedly represent a heterogeneous group, and ... under the cover of 'Type 3,' no single certain disorder is implied." An example is patients with type 3 Gaucher disease with slowing of the horizontal saccadic eye movements as their primary neurologic manifestation $(19,20)$. This form of Gaucher disease, considered by some as type $3 b$ (7), is characterized by severe visceral involvement, including massive hepatosplenomegaly and pancytopenia, severe skeletal involvement and, when untreated, death by adolescence from hepatic or pulmonary complications.

Another specific subtype of neuronopathic Gaucher disease includes patients who develop progressive myoclonic epilepsy. Although this presentation of type 3 Gaucher disease, also referred to as type 3a, was among the first appreciated (7), it is perhaps the least well characterized. Past case reports of patients with Gaucher disease and myoclonic epilepsy have been scattered, and often the myoclonus has not been an emphasized feature. What is remarkable is the variability in age at presentation and the rate of progression of cases. King (21) described a 39 -y-old Jewish male with a 22-y history of progressive myoclonic epilepsy who was subsequently found to have Gaucher disease. Winkleman et al. (22) documented a clinicopathologic study of a family with Gaucher disease where the proband developed synchronous involuntary jerks at age $34 \mathrm{y}$, and his sister, also with Gaucher disease, developed myoclonus at age $50 \mathrm{y}$. Neil et al. (23) described a 41-y-old woman with mild intermittent myoclonic jerking who also had a "mask-like" facies. A case report from Japan described a female patient with myoclonic epilepsy that developed in adolescence (24), and another 22-y-old male patient was described from Germany (25). A few of the adult patients have also been found to have Parkinson-like symptoms $(11,23)$. On the other end of the age spectrum, Grover et al. (26) reported two second cousins with Gaucher disease, one with myoclonus and spasticity at age $17 \mathrm{mo}$ and the second with continuous myoclonus at age $8 \mathrm{y}$. In two other reports from Europe, the myoclonus developed at $16 \mathrm{mo}$ (27) and at $4.5 \mathrm{y}$ (28). Verghese et al. (29) described the clinical and neuropathologic findings in a 6-y-old patient who was found to have selective degeneration of the cerebellar dentate nucleus and the dentatorubrothalamic pathway.

Several of the features described in this subgroup of patients, including the horizontal gaze abnormality, progressive dementia, generalized epilepsy, ataxia, and spasticity, are also seen in a group of patients with type 3 Gaucher disease from the
Norrbottnian geographic isolate in northern Sweden (30). Although all Norrbottnian patients are believed to share the genotype L444P/L444P, the age and rate of symptom progression is also quite variable in this group. The median age of death for untreated patients is $12 \mathrm{y}$, the oldest patient described was $47 \mathrm{y}$, and not all patients have developed neurologic symptoms (31). The Swedish investigators specifically comment that myoclonus was not found in their patients (32).

In the past few years, our understanding of the genetic basis of myoclonic epilepsy has progressed rapidly and many different defects and specific genes and mutations have been identified (33-35). Genetic lesions have been elucidated in recessive disorders with a myoclonic component, such as Unverricht-Lundberg disease, Lafora disease, five forms of ceroid lipofuscinosis, $\mathrm{GM}_{2}$ gangliosidosis, and sialidosis; in dominant disorders like dentatorubropallidoluysian atrophy (DRPLA); and in a mitochondrial disorder, MERRF (mitochondrial encephalomyopathy and ragged red fibers).

We believe that a focus on patients with atypical presentations of Gaucher disease will enable us to establish the extent to which DNA mutations correlate with specific phenotypes, and will ultimately help in the identification of other factors that contribute to disease manifestations in this disorder. Thus, in this study, we chose to examine the phenotypes, mutations, and proteins encountered in 16 patients with type 3 Gaucher disease associated with progressive myoclonic epilepsy.

\section{MATERIALS AND METHODS}

Case reports. The case histories of the 16 patients studied are briefly summarized in Table 1 . These included all available patients with Gaucher disease and myoclonic epilepsy referred to the National Institutes of Health between 1981 and 2001, with the exception of two patients with Parkinson-like features described elsewhere $(11,36)$. Several of the cases have been previously described in the literature. The cell line for patient 3 was purchased from the National Institute of General Medical Sciences Human Genetic Mutant Cell Repository. All other patient samples and clinical data were obtained with informed consent under protocols approved by the National Institute of Mental Health and National Institute of Neurological Disorders and Stroke Institute Review Boards. The clinical records and genotypes of 24 children with abnormal saccadic eye movements described previously (20) were also reviewed. Frozen autopsy samples from control individuals were purchased from the Cooperative Human Tissue Network (Philadelphia, PA, U.S.A.).

DNA and RNA preparation. High molecular weight DNA and total RNA were isolated from white blood cells, cultured fibroblast or lymphoblast cell lines, or tissues of affected individuals and normal controls as previously described (37).

Mutation analysis and Southern blots. The patient DNA sequences were initially screened for common mutations, including N370S, L444P, R463C, c.84-85insG, IVS2 +1G $\rightarrow$ A, and c.1263-1317del as previously described $(38,39)$. To confirm these mutations and to identify others, direct sequencing of amplified PCR fragments was performed using PCR sequencing primers described previously (17). All 11 exons and 


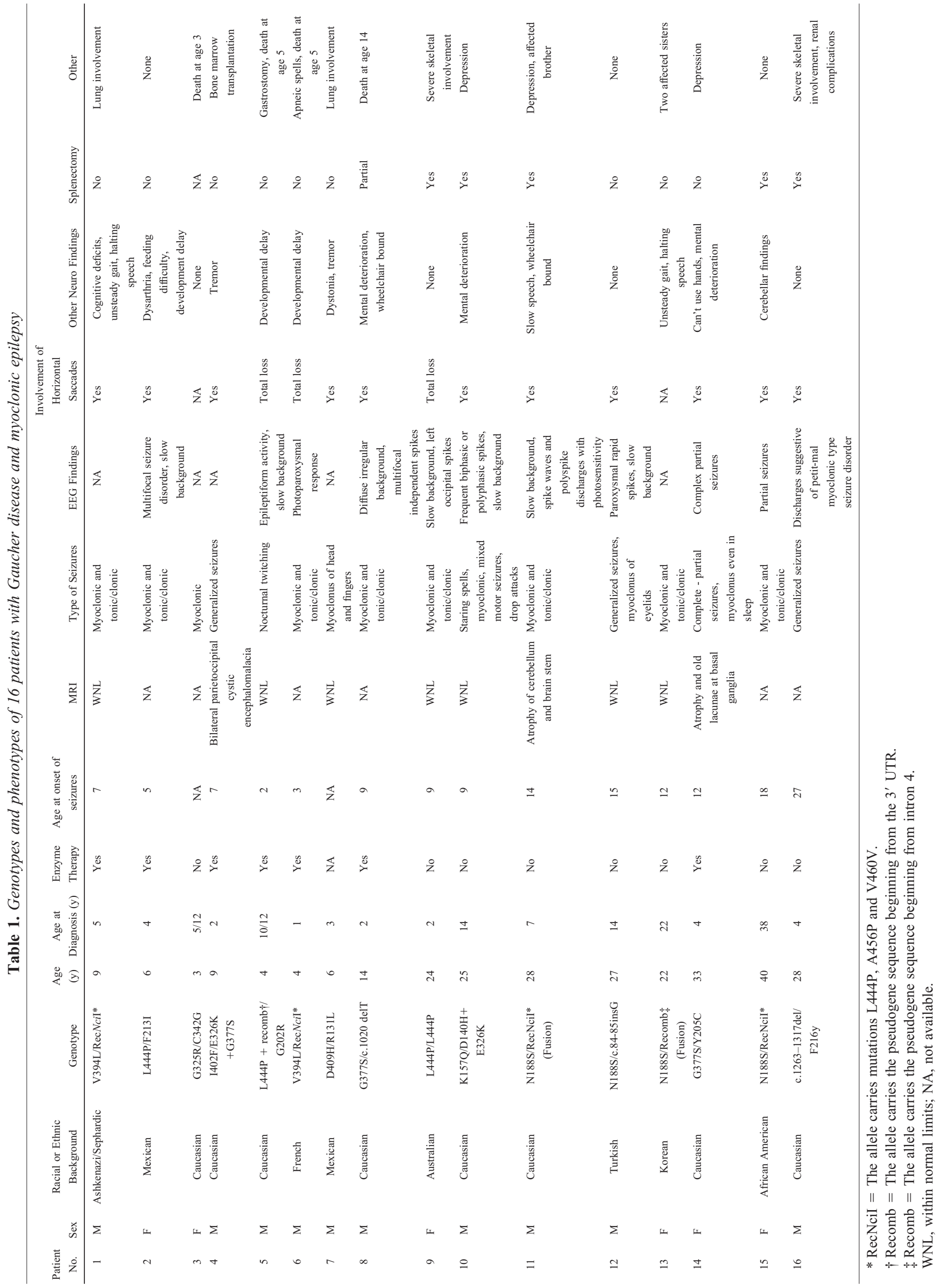


the surrounding intronic regions were sequenced. In addition, Southern blot analyses using the restriction enzymes $S s p$ I and HincII and long template PCR were performed to look for any large deletions, recombinations or duplications as previously described (39-41).

RNA analysis. Northern blots were performed using total RNA isolated from cell pellets and hybridized to ${ }^{32} \mathrm{P}$ random prime-labeled glucocerebrosidase and $\beta$-actin cDNA as described (39).

Enzyme assay and Western blot. Total protein was extracted from frozen cell pellets of fibroblasts or lymphoblasts. Glucocerebrosidase activity was measured using 4-methyl umbelliferyl $\beta$-D-glucopyranoside as a substrate (42). Western blots were performed using 15-30 $\mu \mathrm{g}$ of protein electrophoresed on an $8 \%$ SDS-PAGE-Tris glycine gel, transferred, and immunoblotted with a polyclonal antibody to human glucocerebrosidase as previously described (39).

Quantitation of glucosylsphingosine levels. The substrate glucosylsphingosine was measured in brain samples from two subjects, aged 14 and $27 \mathrm{y}$ (patients 8 and 16), obtained at autopsy using HPLC with a 4-fluoro 7- nitrobenzofurazangenerated autofluorescent derivative (43). Levels were compared with those measured in brain samples from seven adults with unrelated diagnoses and from two children, aged 4 mo and $31 / 2 \mathrm{y}$, obtained at autopsy.

\section{RESULTS}

Clinical findings. The 16 cases studied included subjects from a variety of races and ethnic backgrounds from four different continents (Table 1). Consanguinity was not reported in any of the cases. Patients 11 and 13 had other siblings with both Gaucher disease and myoclonus, whereas patient 10 had an adult brother with Gaucher disease who shared the same genotype but who lacked neurologic manifestations (44). Several of the clinical features were shared by all 16 patients and others were more variable.

Clinically, the patients could be subgrouped into two categories based upon whether neurologic findings presented in early childhood or later in adolescence or adulthood. All of the patients tested had a horizontal supranuclear gaze palsy. Patients 1 through 9 were diagnosed with Gaucher disease by age $4 \mathrm{y}$ and seizures developed by age 9 . This group generally had significant visceral and/or skeletal involvement and four died in childhood. Cognitive deficits and delayed development were also frequently noted.

The second category included seven adults with myoclonic seizures (patients 10-16). These ranged from age 22 to $40 \mathrm{y}$ at the time of evaluation. In three of these cases, the diagnosis of Gaucher disease was made in early childhood, but neurologic involvement manifested slowly. In fact, in case 16, seizures did not develop until age 27. Of note, in three patients (cases 9, 13, and 15), seizures preceded the diagnosis of Gaucher disease. Among the adult patients, mental deterioration and speech involvement were observed, often accompanied by clinical depression.

Another observation was that almost all of the patients studied had generalized seizures in addition to myoclonus, and other abnormalities were noted on EEG. While most of the subjects evaluated had normal cranial MRI evaluations, atrophy was noted in two adults and one child (case 4) appeared to have bilateral parietoccipital encephalomalacia. Seven of the subjects studied received enzyme replacement therapy. The myoclonus was not reported to improve with therapy.

Genotypic analysis. The genotypes of the 16 patients are listed in Table 1.

Selected exons of patient DNA were initially screened for the four commonly encountered mutations, IVS $2+1 \mathrm{G} \rightarrow \mathrm{A}$, c.84-85insG, N370S, and L444P. N370S and IVS2 +1G $\rightarrow$ A were not encountered in this group of patients, whereas the c.84-85insG mutation was present on only one allele. The L444P mutation was found on one allele in two patients, on both alleles in one patient, and as part of a recombinant allele in five others. All 11 exons and splice junctions of the glucocerebrosidase gene were then sequenced in DNA from each patient both to confirm these mutations and to identify the remaining mutant alleles and to establish whether more than one mutation was present on a given allele. All 32 mutant alleles were identified. Table 2 summarizes what is known from the literature regarding the different mutations identified in these patients.

Several rare alleles and genotypes were noted in patients in our sample. Of the 14 different genotypes detected in our sample of 16 patients, the genotype V394L/RecNciI allele was shared by two patients and the genotype N188S/RecNciI allele was shared by another two patients. In addition, one patient had the genotype N188S/c.84-85insG. Two patients had the mutation E326K allele as a second mutation on the same allele with another glucocerebrosidase mutation. This substitution may be a polymorphism, for it has also been identified in normal controls (45).

Southern blot analyses using $S s p$ I revealed abnormal bands in three individuals (Fig. 1). Patient 5, with genotype G202R/L444P, had a previously described gene rearrangement on $1 \mathrm{q} 21$ that introduced a duplication of the glucocerebrosidase pseudogene and a metaxin fusion gene (46). This resulted in a $17 \mathrm{~kb}$ band on Ssp I digestion (Fig. 1) and also an extra band on HincII digestion. An additional band in the $S s p$ I digest of DNA from patient 11 reflected a previously described fusion allele where the site of fusion between the glucocerebrosidase gene and pseudogene occurred between the end of intron 9 and the beginning of exon 10 (39). The extra band observed on Southern blot of DNA from patient 13 resulted from a novel fusion allele, where the site of fusion was established by sequence comparison to be in intron 4 . Southern blot analyses using the restriction enzymes SstII and HincII confirmed these results (data not shown).

Transcriptional studies. Northern blots were prepared using total RNA extracted from the 11 available patient cell lines (patients 1, 2, 5-7, 9-12, 14, and 15) and hybridized to both glucocerebrosidase and $\beta$-actin cDNA probes. A transcript with an appropriate size and band intensity was detected in all samples when standardized to $\beta$-actin. Quantitative differences in glucocerebrosidase were not found between patient and control samples (data not shown).

Western analyses. Protein extracts were available from 11 of the patients studied (patients 1-3, 5-7, 9, 10, 12, 14, and 15). 
Table 2. What Is Known about These Mutations

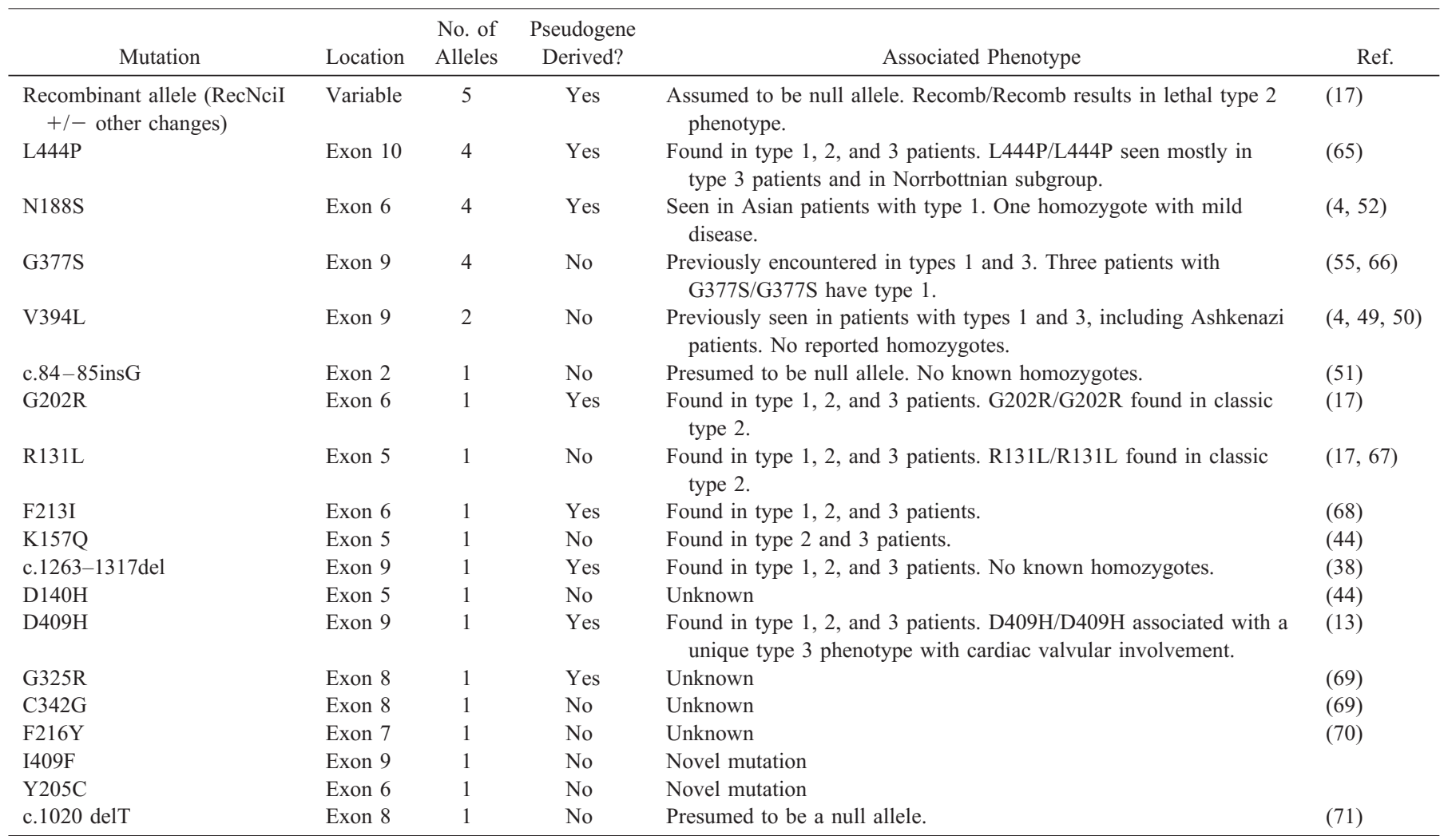
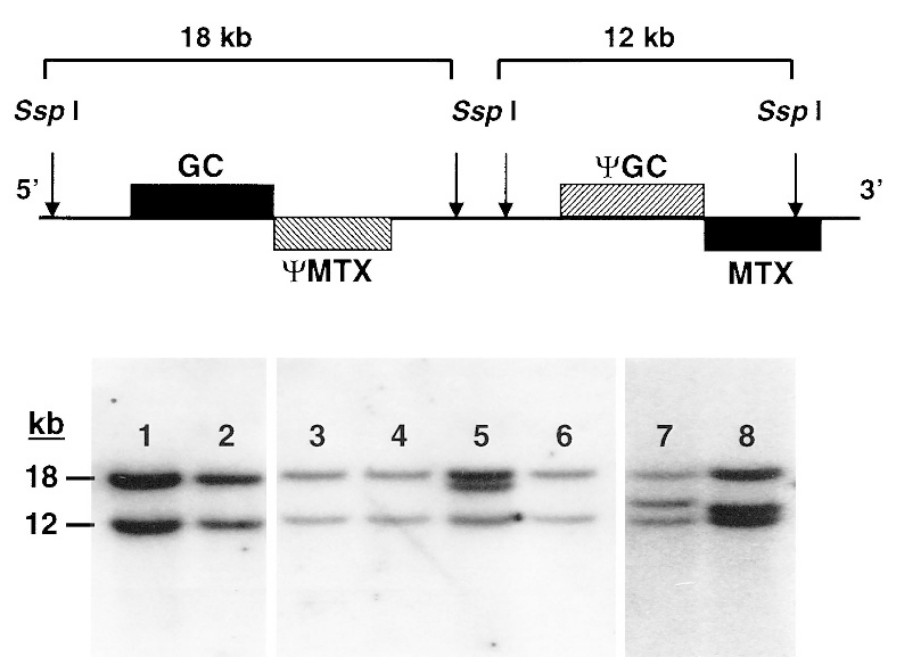

Figure 1. (A) Schematic of the glucocerebrosidase gene locus, showing the genes and pseudogenes for glucocerebrosidase and metaxin. The normal $S s p$ I sites are indicated by arrows. (B) Southern blot of SspI-digested genomic DNA from patients and normal control probed with a labeled glucocerebrosidase cDNA. The expected 18 and $12 \mathrm{~kb}$ bands are observed in the control lanes and in all of the patient samples. Lanes 1, 3: normal controls; lanes 2, 4, and 6: patients carrying a RecNciI allele derived from a gene conversion event; lane 5: patient 5, showing $17 \mathrm{~kb}$ duplication allele; lanes 7 and 8: patients 11 and 13 , respectively, showing fusion alleles resulting from crossover between the glucocerebrosidase gene and pseudogene.

The residual enzyme activity measured in lymphoblasts or fibroblasts (Table 3 ) was found to be $<5 \%$ of control activity in eight patients, but between $7.5 \%$ and $26 \%$ of control activity in the three others (Table 3). There was no correlation between the level of residual enzyme activity and the age of the patient or severity of symptoms. On Western blots using polyclonal antibody to human glucocerebrosidase, all of the patients evaluated had the $61 \mathrm{kD}$ form of the enzyme, and three showed the $63 \mathrm{kD}$ band (Table 3). As previously reported in other patients with neuronopathic Gaucher disease $(47,48)$, none of the patients had the $56 \mathrm{kD}$ form, which was clearly shown in samples from controls and from two patients with type 1 Gaucher disease.

Quantitation of glucosylsphingosine in brain samples. Brain autopsy samples were available from two subjects, patients 8 and 16. The glucosylsphingosine levels were measured to be 22 and $32 \mathrm{ng} / \mathrm{mg}$ protein, respectively. In contrast, samples from nine pediatric and adult control brains were found to range from 0.04 to $1.2 \mathrm{ng} / \mathrm{mg}$ protein with an average value of $0.63 \mathrm{ng} / \mathrm{mg}$ protein.

\section{DISCUSSION}

The phenotypic analysis of this series of 16 patients with type 3 Gaucher disease substantiates the existence of a subgroup of patients sharing the rare finding of progressive myoclonic epilepsy, yet the wide range of clinical presentations found in these patients demonstrate that this is not a discrete phenotype. There was no characteristic age of onset nor predicted rate of clinical progression. This was also seen in a close evaluation of patients with type 2 Gaucher disease $(17,39)$ and supports the view of Gaucher disease as having a continuum of manifestations. In fact, patients with type 2 Gaucher disease that live longer also often develop myoclonic seizures (unpublished observation). 
Table 3. Protein Studies

\begin{tabular}{|c|c|c|c|c|}
\hline $\begin{array}{l}\text { Patient } \\
\text { No. }\end{array}$ & Genotype & $\begin{array}{l}\text { Residual Enzyme Activity } \\
\text { ( } \% \text { of Control) }\end{array}$ & $\begin{array}{c}\text { Pattern on Western Blot } \\
\text { (Glucocerebrosidase Isoform) }\end{array}$ & Cell Type Studied \\
\hline 1 & V394L/RecNciI & $0.3 \%$ & $61 \mathrm{kD}$ & Lymphoblast \\
\hline 2 & L444P/F213I & $7.6 \%$ & $61 \mathrm{kD}$ & Fibroblast \\
\hline 3 & $\mathrm{G} 325 \mathrm{R} / \mathrm{C} 342 \mathrm{G}$ & $25.7 \%$ & $63 \mathrm{kD}, 61 \mathrm{kD}$ & Fibroblast \\
\hline 4 & $\mathrm{I} 402 \mathrm{~F} / \mathrm{E} 236 \mathrm{~K}+\mathrm{G} 377 \mathrm{~S}$ & NA & NA & NA \\
\hline 5 & L444P + Recombinant/G202R & $2.8 \%$ & $61 \mathrm{kD}$ & Fibroblast \\
\hline 6 & V394L/RecNciI & $2.5 \%$ & $63 \mathrm{kD}, 61 \mathrm{kD}$ & Fibroblast \\
\hline 7 & D409H/R131L & $3.5 \%$ & $61 \mathrm{kD}$ & Fibroblast \\
\hline 8 & G377S/c.1020 delT & $5.7 \%$ & NA & Fibroblast \\
\hline 9 & $\mathrm{~L} 444 \mathrm{P} / \mathrm{L} 444 \mathrm{P}$ & $3.6 \%$ & No signal & Fibroblast \\
\hline 10 & $\mathrm{~K} 157 \mathrm{Q} / \mathrm{D} 140 \mathrm{H}+\mathrm{E} 236 \mathrm{~K}$ & $2.9 \%$ & $61 \mathrm{kD}$ & Fibroblast \\
\hline 11 & N188S/RecNciI & NA & NA & NA \\
\hline 12 & N188S/c.84-85insG & $2.0 \%$ & NA & Lymphoblast \\
\hline 13 & N188S/Recombinant & NA & NA & NA \\
\hline 14 & G377S/Y205C & $5.2 \%$ & $61 \mathrm{kD}$ & Fibroblast \\
\hline 15 & N188S/RecNciI & $24.2 \%$ & $63 \mathrm{kD}, 61 \mathrm{kD}$ & Fibroblast \\
\hline 16 & c. $1263-1317 \mathrm{del} / \mathrm{F} 216 \mathrm{Y}$ & NA & NA & NA \\
\hline
\end{tabular}

The major associated clinical finding shared by all 16 patients was the slowing of the horizontal saccadic eye movements (19). This continues to be a feature common to all patients with type 3 Gaucher disease, independent of the extent of non-neurologic manifestations. This is in contrast to the conclusions of Patterson et al. (7), who felt that oculomotor abnormalities were predictive of severe visceral involvement. The other shared clinical finding among these patients was an abnormal EEG, often with generalized seizures.

On the other hand, many clinical features encountered in the group were quite variable, including age; sex; ethnic background; the degree of visceral, skeletal, cognitive, and cerebellar involvement; and MRI findings. There did appear to be two partially distinct subgroups of patients, the first with onset of myoclonus in early childhood associated with significant developmental and/or cognitive delays, severe visceral involvement, and early death. The second group presented later, generally with slower deterioration and less severe systemic manifestations and many were still alive in their 20s and 30s. The existence of this second group with onset of myoclonus at a later age emphasizes the need for careful longitudinal follow-up of all patients with neuronopathic Gaucher disease. Also, the distinction between the two separate groups provides evidence for the contribution of modifying factors other than the deficiency in glucocerebrosidase.

Among the 16 genotypes encountered, few were shared and there was genotypic heterogeneity even among similar patients with the most severe presentations. Thus, in general, the clinical course could not be accurately predicted by genotype. In addition, no transcriptional differences were observed in patients with this phenotype, and the range in residual enzyme activity did not correlate with severity or the age at onset.

Several rare mutant alleles were encountered in this population in a frequency that was greater than expected. Allele V394L was identified in two children, in both cases together with RecNciI, a recombinant allele that is presumed to be a null mutation. Another group also reported a child with myoclonic epilepsy who died at age 6 y with genotype V394L/ recombinant (RecTL) and demonstrated the V394L allele pro- duced small amounts of functional enzyme, which was $\mathrm{pH}$ sensitive (29). Mutation V394L has been reported in patients with type 1 and type 3 Gaucher disease and is a rather common mutation among Ashkenazi Jewish patients $(4,49,50)$. However, one patient with genotype V394L/L444P has been described with very mild type 1 Gaucher disease (4).

Mutation N188S was another rare mutation found in four adult patients of different ethnic origins, each with onset of seizures at or after age $12 \mathrm{y}$. Three of these patients had recombinant alleles as the second mutant allele, although the site and mechanism of recombination varied, and the fourth individual carried c.84-85insG, an early frameshift mutation, which is also presumably a null mutation (51). Mutation N188S was first described in Korean and Chinese patients (52) and it was speculated that it could be neuroprotective in this population. One patient with type 1 Gaucher disease was reported to be homozygous for mutation N188S $(52,53)$. Likewise, mutation G377S, found in two patients in our series, has previously been considered a mild mutation and three Portuguese patients with type 1 disease have been described who are homozygous for G377S $(54,55)$.

Of note, 18 of 32 mutant alleles encountered in our patient series were pseudogene derived, including recombinant alleles, c.1263-1317 del, N188S, F131I, G202R, G325R, D409H, and L444P. Patient 16 had a known 55 bp deletion that is derived from the pseudogene (38) and patient 5 was found to have another previously described downstream duplication in addition to two glucocerebrosidase point mutations (46). Five patients had sequence changes that would have been identified as mutation RecNciI, encompassing pseudogene-derived sequence, including mutations L444P, A456P, and V460V. Southern blots and sequencing determined that, in fact, the site and mechanism of recombination differed in the five alleles. Two patients had fusion alleles; in patient 13, the site of fusion appeared to be in intron 4 , whereas in patient 11 it was at the end of intron 9 or the beginning of exon 10 (Fig. 1). Close examination of the intronic sequence in patients 1,6 , and 15 showed that the recombinant allele resulted from gene conversion events. In patients 1 and 6 , the converted segment in- 
cluded a part of intron 11, whereas in patient 15 , the intron 11 sequence corresponded to the gene rather than pseudogene, reflecting gene conversion stretches of different sizes.

Two novel mutations were identified in this series: I402F, located in exon 9, and Y205C, located in exon 6, both with mutation G377S on the second allele. Although the two mutations are clearly not "neuroprotective," it is not possible to determine whether the novel mutation, the G377S allele, or both defined the phenotype.

We contrasted the genotypes encountered in patients with myoclonic epilepsy with a second previously described subgroup of patients with type 3 Gaucher disease $(4,20)$, a series of 24 children with significant visceral and skeletal manifestations who had slowing of the saccadic eye movements as their sole neurologic manifestation (Table 4). Although eight different genotypes were identified, over half of the children were homozygous for point mutation L444P. The second most common mutation found in 10 children was R463C, seen only as a heterozygous mutation together with a null mutation such as RecNciI, c.84-85insG, or IVS2+1G $>$ A. Actually, only one child carried neither L444P nor R463C. This was a male who died of pulmonary complications at age $4 \mathrm{y}$, who carried mutation G377S. Notably, mutations N188S and V394L were not found among the type 3 patients without myoclonus.

Thus, generally the genotypes of the patients with myoclonic epilepsy differed significantly from those with horizontal supranuclear gaze palsy without myoclonus. Mutation R463C and homozygosity for L444P were not associated with seizures, with the exception of patient 9 . This child was diagnosed with Gaucher disease at age 19 mo, was splenectomized because of severe thrombocytopenia at age $3 \frac{1}{2}$ years and had severe skeletal involvement including chronic osteomyelitis and severe kyphosis with pulmonary restriction. Her oculomotor abnormality was identified in early childhood and seizures and an abnormal EEG were reported by age $9 \mathrm{y}$. At age $18 \mathrm{y}$, she was described as having jerky episodes involving the upper extremities, and physical examination at age 24 y described a wheelchair-bound woman with cognitive defects and gross myoclonus of the upper extremities. Therefore, although myoclonus was not mentioned at an early age, it later became a prominent feature of her disorder.

This study was conducted to extend the wealth of accumulated information on genotype/phenotype correlation in Gaucher disease by examining a rare subset of patients with progressive myoclonic epilepsy. Of note, no patients carrying

Table 4. Genotypes encountered in 24 patients with type 3 Gaucher disease, horizontal supranuclear gaze palsy, and severe visceral involvement without myoclonic epilepsy

\begin{tabular}{lc}
\hline \multicolumn{1}{c}{ Genotype } & No. of Patients \\
\hline L444P/L444P & 13 \\
R463C/Recombinant allele & 3 \\
R463C/c.84-85insG & 2 \\
R463C/IVS2+1G $>$ A & 2 \\
R463C/D399N & 1 \\
R463C/Y304X & 1 \\
R463C/A176P & 1 \\
G377S/A190T & 1 \\
\hline
\end{tabular}

Most of this data was previously published in references 4, 8 and 20 . mutation N370S were identified. Three glucocerebrosidase point mutations do appear to be associated with this form of the disorder-V394L, N188S, and G377S-although each has also been seen in other types of Gaucher disease. Although it would be premature to suggest that the identification of these mutations is predictive, any patients carrying one of these three mutations without N370S should be carefully evaluated for the development of myoclonic epilepsy. The reason for this apparent genotype/phenotype association is unclear. Although structurally, the protein alterations introduced by any of the mutations do not appear to be dramatic, the complete threedimensional structure of glucocerebrosidase is not available, and therefore the potential contribution of these changes to protein conformation is unknown. Actually, although the residual enzyme activity did not correlate well with severity, the results of the Western blot studies were more consistent. The identification of multiple molecular forms of glucocerebrosidase has previously been shown to provide a basis for discrimination between the neuronopathic and non-neuronopathic Gaucher phenotypes $(47,48)$. Normal fibroblasts have two major forms with apparent molecular weight of approximately $63 \mathrm{kD}$ and $56 \mathrm{kD}$, and a minor form of $61 \mathrm{kD}$. We confirmed that the smaller processed $56 \mathrm{kD}$ form is not found in neuronopathic Gaucher disease, suggesting that processing is incomplete. It also indicates that although the patients studied had diverse genotypes, there was a shared property at the protein level, which is likely to be the result of post-translational processing, compartmentalization, and/or protein stability.

The 35- to 50-fold increase in brain glucosylsphingosine levels observed in two patients in this series at autopsy may also be relevant. Thus far, elevations in brain glucosylsphingosine levels have been detected in all neuronopathic patients studied, with or without myoclonus. Perhaps the potentially neurotoxic effect of this substrate contributes to a vulnerability to myoclonus.

The myoclonus seen in Gaucher disease is cortical in origin and is known to be associated with a marked increase in the amplitude of the somatosensory evoked potential, or "giant potential" indicating a defect of inhibitory input into the cerebral cortex $(56,57)$. However, because it was recently demonstrated that the amplitude finding of the somatosensory evoked potential is also elevated in type 3 Gaucher patients who do not have myoclonus, this is not necessary predictive of the development of seizures (58) but overt myoclonus in Gaucher disease could be the extreme manifestation of a general cortical pathogenic process.

The finding that specific mutant glucocerebrosidases may be associated with the development of myoclonic epilepsy suggests that the abnormal enzyme might have a modifying role on other proteins involved in epilepsy. Recently, genes for other forms of progressive myoclonic epilepsy have been determined, including MERRF (59), Unverricht-Lundborg (EPM1) (60), neuronal ceroid lipofucinosis (CLN3) (61), and Lafora disease (EPM2) (62). Many of these disorders share clinical features with patients in our series. It may be worthwhile both to screen DNA from our patients for mutations in other genes known to be associated with early onset myoclonic epilepsy, 
including cystatin B and laforin, and to screen patients with myoclonic epilepsy for glucocerebrosidase deficiency.

Of note, several different lysosomal storage disorders, including late-onset $\mathrm{GM}_{2}$ gangliosidosis, $\mathrm{GM}_{1}$ gangliosidosis type 2, Niemann Pick disease, sialidosis, galactosialidosis, arylsulfatase A pseudodeficiency, and some forms of ceroid lipofuscinosis, have been associated with myoclonic epilepsy $(63,64)$. It is intriguing to speculate that these disorders could share a common abnormality related to lysosomal targeting or processing that contributes to this rare phenotype. Therefore, although the analysis of mutations encountered in patients with Gaucher disease with myoclonic epilepsy provides some insight into genotype/phenotype correlation in this disorder, these studies reinforce the magnitude of what we still do not understand about the mechanisms of neurologic disease. Our results indicate that the identification of other factors in addition to the point mutations, both environmental and genetic, will ultimately clarify why certain patients with Gaucher disease develop myoclonic epilepsy. Moreover, the insights gained through the study of these patients will likely have implications that will be relevant to understanding both the development of progressive myoclonic epilepsy and the pathogenesis of Gaucher disease.

Acknowledgments. The authors thank Dr. Sihoun Hahn, Dr. Jennifer MacKenzie, Dr. Gregory Pastores, and Dr. Erdem Tuzun for their generous contributions of clinical information and samples. We also thank Marie Hall for secretarial assistance.

\section{REFERENCES}

1. Alfonso P, Cenarro A, Peréz-Calvo JI, Giralt M, Giraldo P, Pocoví M 2001 Mutation prevalence among 51 unrelated Spanish patients with Gaucher disease: identification of 11 novel mutations. Blood Cells Mol Dis 27:882-891

2. Grabowski GA, Horowitz M 1997 Gaucher's disease: molecular, genetic, and enzymological aspects. Baillieres Clin Haematol 10:635-656

3. Beutler E, Gelbart T 1998 Hematologically important mutations: Gaucher disease. Blood Cells Mol Dis 24:2-8

4. Koprivica V, Stone DL, Park JK, Callahan M, Frisch A, Cohen IJ, Tayebi N, Sidransky E 2000 Analysis and classification of 304 mutant alleles in patients with type 1 and type 3 Gaucher disease. Am J Hum Genet 66:1777-1786

5. Orvisky E, Park JK, Parker A, Walker JM, Martin BM, Stubblefield BK, Uyama E, Tayebi N, Sidransky E 2002 The identification of eight novel glucocerebrosidase mutations in patients with Gaucher disease. Hum Mutation 19:458-459

6. Beutler E, Grabowski 2001 Gaucher disease. In: Scriver CR, Beaudet AL, Valle D, Sly WS (eds) The Metabolic and Molecular Bases of Inherited Disease. McGraw-Hill, New York, pp 3635-3668

7. Patterson MC, Horowitz M, Abel RB, Currie JN, Yu K-T, Kaneski C, Higgins JJ, O'Neill RR, Dedio P, Pikus A, Brady RO, Barton NW 1993 Isolated horizontal supranuclear gaze palsy as a marker of severe systemic involvement in Gaucher's disease. Neurology 43:1993-1997

8. Sidransky E, Bottler A, Stubblefield B, Ginns EI 1994 DNA mutational analysis of type 1 and type 3 Gaucher patients: how well do mutations predict phenotype? Hum Mutat 3:25-28

9. Grabowski GA 2000 Gaucher disease: considerations in prenatal diagnosis. Prenatal Diag 20:60-62

10. Neudorfer O, Giladi N, Elstein D, Abrahamov A, Turezkite T, Aghai E, Reches A, Bembi B, Zimran A 1996 Occurrence of Parkinson's syndrome in type I Gaucher disease. QJM 89:691-694

11. Tayebi N, Callahan M, Madike V, Stubblefield BK, Orvisky E, Krasnewich D, Fillano JJ, Sidransky E 2001 Gaucher disease and parkinsonism: a phenotypic and genotypic characterization. Mol Genet Metab 73:313-321

12. Elstein D, Klutstein MW, Lahad A, Abrahamov A, Hadas-Halpern I, Zimran A 1998 Echocardiographic assessment of pulmonary hypertension in Gaucher's disease. Lancet 351:1544-1546

13. Abrahamov A, Elstein D, Gross-Tsur V, Farber B, Glaser Y, Hadas-Halpern I, Ronen S, Tafakjdi M, Horowitz M, Zimran A 1995 Gaucher's disease variant characterized by progressive calcification of heart valves and unique genotype. Lancet $346: 1000-$ 1003
14. Uyama E, Takahashi K, Owada M, Okamura R, Naito M, Tsuji S, Kawasaki S, Araki S 1992 Hydrocephalus, corneal opacities, deafness, valvular heart disease, deformed toes and leptomeningeal fibrous thickening in adult siblings: a new syndrome associated with glucocerebrosidase deficiency and a mosaic population of storage cells. Acta Neurol Scand 86:407-420

15. Stone DL, Tayebi N, Coble C, Ginns EI, Sidransky E 2000 Cardiovascular fibrosis, hydrocephalus, ophthalmoplegia, and visceral involvement in an American child with Gaucher disease. J Med Genet 37:E40

16. Sidransky E, Sher DM, Ginns EI 1992 Gaucher disease in the neonate: a distinct Gaucher phenotype is analogous to a mouse model created by targeted disruption of the glucocerebrosidase gene. Pediatr Res 32:494-498

17. Stone DL, Tayebi N, Orvisky E, Stubblefield B, Madike V, Sidransky E 2000 Glucocerebrosidase gene mutations in patients with type 2 Gaucher disease. Hum Mutat 15:181-188

18. Frederickson DS, Sloan HR 1975 Glucosylceramide lipidoses: Gaucher's disease. In: Stanbury JB, Wyngaarden JB, Frederickson DS (eds) The Metabolic Basis of Inherited Disease. McGraw-Hill, New York, pp 730-759

19. Cogan DG, Chu FC, Reingold D, Barranger J 1981 Ocular motor signs in some metabolic disease. Arch Ophthalmol 99:1802-1808

20. Sidransky E, Tsuji S, Stubblefield BK, Currie J, FitzGibbon EJ, Ginns EI 1992 Gaucher patients with oculomotor abnormalities do not have a unique genotype. Clin Genet 41:1-5

21. King J 1975 Progressive myoclonic epilepsy due to Gaucher's disease in an adult J Neuro Neurosurg Psychiatry 38:849-854

22. Winkleman MD, Banker BQ, Victor M, Moser HW 1983 Non-infantile neuronopathic Gaucher's disease: a clinicopathologic study. Neurol 33:994-1008

23. Neil JF, Glew RH, Peters SP 1979 Familial psychosis and diverse neurologic abnormalities in adult-onset Gaucher's disease. Arch Neurol 36:95-99

24. Yoshikawa H, Fueki N, Sasaki M, Sakuragawa N 1991 Uncoupling of blood flow and oxygen metabolism in the cerebellum in type 3 Gaucher disease. Brain Dev 13:190-192

25. Seeman PJ, Finckh U, Hoppner J, Lakner V, Liebisch I, Grau G, Rolfs A 1996 Two new missense mutations in a non-Jewish Caucasian family with type 3 Gaucher disease. Neurology 46:1102-1107

26. Grover WD, Tucker SH, Wenger DA 1978 Clinical variation in 2 related children with neuronopathic Gaucher disease. Ann Neurol 3:281-283

27. Conradi N, Kyllerman M, Mansson JE, Percy AK, Svennorholm L 1991 Lateinfantile Gaucher disease in a child with myoclonus and bulbar signs: neuropathological and neurochemical findings. Acta Neuropathol (Berl) 82:152-157

28. Dobbelaere D, Sukno S, Defoort-Dhellemmes S, Lamblin MD, Largilliere C 1998 Neurological outcome of a patient with Gaucher disease type III treated by enzymatic replacement therapy. J Inherit Metab Dis 21:74-76

29. Verghese J, Goldberg RF, Desnick RJ, Grace ME, Goldman JE, Lee SC, Dickson D, Rapin I 2000 Myoclonus from selective dentate nucleus degeneration in type 3 Gaucher disease. Arch Neurol 57:389-395

30. Erickson A 1986 Gaucher disease-Norrbottnian type (III). Neuropaediatric and neurobiological aspects of clinical patterns and treatment. Acta Paediatr Scand Suppl 326:1-42

31. Erikson A, Åström M, Månsson JE 1995 Enzyme infusion therapy of the Norrbottnian (type 3) Gaucher disease. Neuropediatrics 26:205-207

32. Blom S, Erikson A 1983 Gaucher disease-Norrbottnian type. Neurodevelopmental, neurological, and neurophysiological aspects. Eur J Pediatr 140:316-322

33. Stafstrom CE, Tempel BL 2000 Epilepsy genes: the link between molecular dysfunction and pathophysiology. Ment Retard Dev Disabil Res Rev 6:281-292

34. Scheffer IE, Berkovic SF 2000 Genetics of the epilepsies. Curr Opin Pediatr 12:536542

35. Delgado-Escueta AV, Ganesh S, Yamakawa K 2001 Advances in the genetics of progressive myoclonus epilepsy. Am J Med Genet 106:129-138

36. Wong K, Topalogulu H, Tresser N, Schiffmann R 2000 Dementia with Lewy bodies and Parkinson's disease in a type 1 Gaucher disease patient. J Neuropath Exp Neurol 59:141

37. Maniatis T, Fritsch EF, Sambrook J 1989 Molecular cloning: a laboratory manual. Cold Spring Harbor Laboratory, Cold Spring Harbor, New York

38. Tayebi N, Stern H, Dymarskaia I, Herman J, Sidransky E 1996 55-Base pair deletion in certain patients with Gaucher disease complicates screening for common Gaucher alleles. Am J Med Genet 66:316-319

39. Tayebi N, Reissner KJ, Lau EK, Stubblefield BK, Klineburgess AC, Martin BM, Sidransky E 1998 Genotypic heterogeneity and phenotypic variation among patients with type 2 Gaucher's disease. Pediatr Res 43:571-578

40. Tayebi N, Cushner S, Sidransky E 1996 Differentiation of the glucocerebrosidase gene from pseudogene by long-template PCR: implications for Gaucher disease. Am J Hum Genet 59:740-741

41. Tayebi N, Cushner S, Kleijer W, Lau E, Damschroder-Williams PJ, Stubblefield BK, Den Hollander JD, Sidransky E 1997 Prenatal lethality of a homozygous null mutation in the human glucocerebrosidase gene. Am J Med Genet 73:41-47

42. Peters SP, Coyle P, Glew RH 1976 Differentiation of beta-glucosidase in human tissues using sodium taurocholate. Arch Biochem Biophys 175:569-582

43. Orvisky E, Sidransky E, McKinney CE, LaMarca ME, Samimi R, Krasnewich D, Martin BM, Ginns EI 2000 Glucosylsphingosine accumulation in mice and patients with type 2 Gaucher disease begins early in gestation. Pediatr Res 48:233-237

44. Eyal N, Firon N, Wilder S, Kolodny EH, Horowitz M 1991 Three unique base pair changes in a family with Gaucher disease. Hum Genet 87:328-332

45. Park JK, Tayebi N, Stubblefield BK, LaMarca ME, MacKenzie JJ, Stone DL, Sidransky E 2002 The E326K mutation and Gaucher disease: mutation or polymorphism? Clin Genet 61:32-34

46. Tayebi N, Park J, Madike V, Sidransky E 2000 Gene rearrangement on 1q21 introducing a duplication of the glucocerebrosidase pseudogene and a metaxin fusion gene. Hum Genet 107:400-403 
47. Ginns EI, Brady RO, Pirrucello S, Moore C, Sorrell S, Furbish FS, Murray GJ, Tage J, Barranger JA 1982 Mutations of glucocerebrosidase: discrimination of neurologic and non-neurologic phenotypes of Gaucher's disease. Proc Natl Acad Sci U S A 79:5607-5610

48. Erickson AH, Ginns EI, Barranger JA 1985 Biosynthesis of the lysosomal enzyme glucocerebrosidase. J Biol Chem 26:4319-4324

49. Theophilus BD, Latham T, Grabowski GA, Smith FI 1989 Comparison of RNase A, a chemical cleavage and GC-clamped denaturing gradient gel electrophoresis for the defection of mutations in exon 9 of the human acid beta-glucosidase gene. Nucleic Acids Res 17:7707-7722

50. Grace ME, Newman KM, Scheinker V, Berg-Fussman A, Grabowski GA 1994 Analysis of human acid $\beta$-glucosidase by site-directed mutagenesis and heterologous expression. J Biol Chem 269:2283-2291

51. Beutler E, Gelbart T, Kuhl W, Zimran A, West C 1992 Mutations in Jewish patient with Gaucher disease. Blood 79:1662-1666

52. Kim JW, Liou BB, Lai MY, Ponce E, Grabowski GA 1996 Gaucher disease: identification of three new mutations in the Korean and Chinese (Taiwanese) populations. Hum Mutat 7:214-218

53. Choy FY, Wong K, Shi HP 1999 Glucocerebrosidase mutations among Chinese neuronopathic and non-neuronopathic Gaucher disease patients. Am J Med Genet $84: 484-486$

54. Laubscher KH, Glew RH, Lee RE, Okinaka RT 1994 Use of denaturing gradient ge electrophoresis to identify mutant sequences in the beta-glucocerebrosidase gene. Hum Mutat 3:411-415

55. Amaral O, Larcerda L, Marcao A, Pinto E, Tamagnini G, Sa Miranda MC 1999 Homozygosity for two mild glucocerebrosidase mutations of probable Iberian origin. Clin Genet 56:100-102

56. Rothwell JC, Obeso JA, Marsden CD 1984 On the significance of giant somatosensory evoked potentials in cortical myoclonus. J Neurol Neurosurg Psychiatry 47:33-42

57. Manganotti P, Tamburin S, Zanette G, Fiaschi A 2001 Hyperexcitable cortical responses in progressive myoclonic epilepsy: a TMS study. Neurology 57:1793-1799

58. Garvey MA, Toro C, Goldstein S, Alarescu G, Wiggs EA, Hallet M, Schiffmann R 2001 Somatosensory evoked potentials as a marker of disease burden in type 3 Gaucher disease. Neurology 56:391-394

59. Shoffner JM, Lott MT, Lezza AM Seibel P, Ballinger SW, Wallace DC 1990 Myoclonic epilepsy and ragged-red fiber disease (MERRF) is associated with a mitochondrial DNA tRNA(Lys) mutation. Cell 61:931-937
60. Pennacchio LA, Lehesjoki AE, Stone NE, Willour VL, Virtaneva K, Miao J, D'Amato E, Ramirez L, Faham M, Koskiniemi M, Warrington JA, Norio R, de la Chapelle A, Cox DR, Myers RM 1996 Mutations in the gene encoding cystatin B in progressive myoclonus epilepsy (EPM1). Science 271:1731-1734

61. International Batten Disease Consortium 1995 Isolation of a novel gene underlying Batten disease, CLN3. Cell 82:949-957

62. Minassian BA, Lee JR, Herbrick JA, Huizenga J, Soder S, Mungall AJ, Dunham I, Gardner R, Fong CY, Carpenter S, Jardim L, Satishchandra P, Andermann E, Snead III OC, Lopes-Cendes I, Tsui LC, Delgado-Escueta AV, Rouleau GA, Scherer SW 1998 Mutations in a gene encoding a novel protein tyrosine phosphatase cause progressive myoclonus epilepsy. Nat Genet 20:171-174

63. Noebels J 2001 The inherited epilepsies. In: Scriver CR, Beaudet AL, Valle D, Sly WS (eds) The Metabolic and Molecular Bases of Inherited Disease. McGraw-Hill, New York, pp 5807-5832

64. Tinuper P, Plazzi G, Monari L, Sangiorgi S, Pellissier JF, Cerullo A, Provini F, Capellari S, Baruzzi A, Lugaresi E, Montagna P 1994 Arylsulfatase A pseudodeficiency and Lafora bodies in a patient with progressive myoclonic epilepsy. Epilepsia 35:332-335

65. Tsuji S, Choudary PV, Martin BM, Stubblefield BK, Mayor JA, Barranger JA, Ginns EI 1987 A mutation in the human glucocerebrosidase gene in neuronopathic Gaucher's disease. N Engl J Med 316:570-575

66. Kawame H, Hasegawa Y, Eto Y, Maekawa K 1992 Rapid identification of mutations in the glucocerebrosidase gene of Gaucher disease patients by analysis of singlestrand conformation polymorphisms. Hum Genet 90:294-296

67. Sinclair G, Choy FY, Humphries L 1998 A novel complex allele and two new point mutations in type 2 (acute neuronopathic) Gaucher disease. Blood Cells Mol Dis 24:420-427

68. He GS, Grace ME, Grabowski GA 1992 Gaucher disease: four rare alleles encoding F213I, F289Y, T323I and P289L in type I variants. Hum Mutat 1:423-427

69. Eyal N, Wilder S, Horowitz M 1990 Prevalent and rare mutations among Gaucher patients. Gene 96:277-283

70. Beutler E, Gelbart T 1990 Gaucher disease associated with a unique KpnI restriction site: identification of the amino acid substitution. Ann Hum Genet 54:149-153

71. Germain DP, Kaneski CR, Brady RO 2001 Mutation analysis of the acid betaglucosidase gene in a patient with type 3 Gaucher disease and neutralizing antibody to alglucerase. Mutat Res 483:89-94 